

Available online at http://www.banglajol.info/index.php/jard

\title{
Effect of Nature of Trellis on the Performance of Boro Rice and Vegetable Crops Grown in the Ails of Boro Rice Field
}

\author{
M. A. HASAN ${ }^{*}$, S. M. HASAN ${ }^{2} \&$ N. ISLAM ${ }^{3}$ \\ ${ }^{1}$ Department of Agronomy, Hajee Mohammad Danesh Science and Technology University, \\ Dinajpur-5200, Bangladesh \\ ${ }^{2}$ Ministry of Shipping, Bangladesh Secretariat, Dhaka, Bangladesh \\ ${ }^{3}$ Department of Agronomy, Bangladesh Agricultural University, Mymensingh-2202, Bangladesh
}

\begin{abstract}
An experiment was conducted at the Agronomy Field Laboratory, Bangladesh Agricultural University, Mymensingh during the period from December 2004 to May 2005 to determine the most effective kind of trellis for the rice-cum-vegetable production system. The treatments consisted of five crop combinations viz. $C_{0}$ : rice alone i.e. control, $C_{1}$ : rice + bottle gourd, $C_{2}$ : rice + white gourd, $C_{3}$ : rice + snake gourd and $C_{4}$ : rice + bitter gourd, and four levels of trellises viz. $T_{1}$ : flat trellis, $T_{2}: T$-trellis (180 $\mathrm{cm}$ breadth), $T_{3}: T$-trellis (240 $\mathrm{cm}$ breadth) and $T_{4}: X$-trellis (cross trellis). The experiment was laid out in randomized complete block design with three replications. Vegetable seeds were sown directly in the pit made on ails of Boro rice field. Later, vegetable crops were supported by trellis made with bamboo and plastic rope arrangements. Results showed that yield and yield contributing characters of Boro rice along with vegetable and rice equivalent yields varied significantly due to crop combination, nature of trellis and their interactions. The trellis-grown bitter gourd $\left(C_{4}\right)$ and bottle gourd $\left(C_{1}\right)$ did not significantly reduce rice yields compared to that obtained from sole rice plot. Grain yields reductions due to trellis-grown vegetable were just marginal. Regarding vegetable yield, white gourd $\left(C_{2}\right)$ on the ails of Boro rice plots gave the highest yield of 14.52 tha $^{-1}$ followed by 9.73 tha ${ }^{-1}$ of bottle gourd $\left(C_{1}\right)$. In respect of cost of production, both flat trellis $\left(T_{1}\right)$ and $T$-trellis with $180 \mathrm{~cm}$ breadth $\left(T_{2}\right)$ were found to be the most suitable trellises for Boro rice-cum-vegetable cultivation on the ails of growing rice crop.
\end{abstract}

Key words: Trellis, performance, vegetable crops, Ail, Boro rice.

\section{INTRODUCTION}

Rice (Oryza sativa L.) is the staple food crop of Bangladesh agriculture covering $80 \%$ of the total land area and it provides the ultimate entity of most of the people. The geographical and agroclimatic conditions of Bangladesh are favourable for rice cultivation. So, the cropping patterns prevailing in the country are dominated by rice. Rice is grown here round the year in Aus, Aman and Boro seasons. Rice holds the area of 10.78 million hectares with a production of 25.19 million tons of grain (BBS, 2004).

\footnotetext{
* Corresponding author: Associate Professor, Department of Agronomy, Hajee Mohammad Danesh Science and Technology University, Dinajpur-5200, Mobile: 01711933871,E-mail: mahasan_uni@yahoo.com

(C) 2009 School of Agriculture and Rural Development, Bangladesh Open University, All rights reserved.
} 


\section{A. Hasan et al.}

In Bangladesh, the arable land is decreasing by approximately $1.0 \%$ of the total area per annum in view of the alarming population growth rate, rapid industrialization and urbanization and hence, the demand for food grain is ever increasing (Anonymous, 2006). In context of the growing demand for food, an additional need to raise crop production per unit area is being felt seriously. Now, in order to increase and stabilize agricultural production the means that has greatly received the attention of scientists in the recent years is multiple cropping or intercropping. In this form of production practice, more than one crop is grown simultaneously or in sequence on the same piece of land (Harwood, 1973). Very recently vegetable production on the ails of rice fields, a new concept of multiple cropping has been under proposition in conditions of Bangladesh, which might produce high potentiality in terms of total production and economic return. In the rice dominating production system of Bangladesh, any sustainable vegetable production technique is essentially lacking. Vegetable crops excluding potato occupy only $1.8 \%$ of the total cropped area with a gross production of 1.63 million tons (BBS, 2004). Therefore, the availability of vegetable in Bangladesh is exceedingly low when compared with other countries. The cereal consumption is the highest here and vegetable consumption is the lowest. The people of developed countries consume a great part of their food in the form of vegetable. In most of the developed countries more than $40 \%$ of the plant-based food comes from vegetable (Siddique and Aditya, 1992). Increasing the land area for vegetable production in Bangladesh seems to have little scope, because of decreasing trend in the land-man ratio. Thus, in these circumstances, in addition to using the conventional methods, the production of vegetable should also be trialed by adopting some unconventional methods like growing several vegetable crops on the ails (the border of rice plots that is used mainly for control of water movement is popularly known as ails all over Bangladesh) of rice crops may be explored. On the other hand, nature of trellis is an important area of examination as the trellises are supposed to provide shade to the rice crops growing underneath the vegetable canopy. The size and placement of trellis were also important because all the vegetable crops were of vine type and they had to need more space for trellis than it cultivated only on the ails of rice field. That is why it was essential to utilize the vertical space without having any effect or a little effect on rice crop grown underneath. So, it is of prime need to improve the system based productivity and put emphasis not only on rice but also simultaneously on production of vegetable crops within the rice fields in the special technique on the raised ail system together with using specialized trellis technique to support vegetable across the rice fields. The present piece of research work was, therefore, undertaken to select the most effective kind of trellis for the rice-cum-vegetable production system.

\section{MATERIALS AND Methods}

The experiment was conducted at the Agronomy Field Laboratory, Bangladesh Agricultural University, Mymensingh during the period from December 2004 to May 2005 with a view to observing the effect of selected nature of trellis on the performance of vegetable crops in the ails of Boro rice field. The treatments consisted of five crop combinations, viz. $\mathrm{C}_{0}$ : rice alone i.e. control, $\mathrm{C}_{1}$ : rice + bottle gourd, $\mathrm{C}_{2}$ : rice + white gourd, $\mathrm{C}_{3}$ : rice + snake gourd and $\mathrm{C}_{4}$ : rice + bitter gourd, and four selected nature of trellises viz. $T_{1}$ : flat trellis, $T_{2}$ : T-trellis $\left(180 \mathrm{~cm}\right.$ breadth), $T_{3}$ : T-trellis (240 $\mathrm{cm}$ breadth) and $\mathrm{T}_{4}$ : $\mathrm{X}$-trellis (cross trellis). The experiment was laid out in randomized complete block design with three replications and the unit plots measured $4.0 \mathrm{~m} \times 2.5 \mathrm{~m}$ each. Boro rice cv.BRRI dhan 29 was fertilized at the rate of $304,77,60,29$ and $5 \mathrm{~kg} \mathrm{ha}^{-1}$ of urea, triple superphosphate, muriate of potash, gypsum and zinc sulphate, respectively (BRRI, 2004). Except urea, the whole amount of other fertilizers was applied at the final land preparation. Urea was top dressed at 20 and 55 days after transplanting of rice. Rice seedlings of 45 day-old were transplanted on 14 January 2005 in $25 \mathrm{~cm}$ apart rows with two seedlings hill ${ }^{-1}$ maintaining a distance of $15 \mathrm{~cm}$ from hill to hill. The pits on ails were prepared with different kind of fertilizers and manures according to dike cropping manual (Alam, 2000). Vegetable seeds were sown directly in the pit made on ails of Boro rice field on February 2005 maintaining a distance of $50 \mathrm{~cm}$ from pit to pit. It was possible to sow vegetable seeds directly, as because the old ails of the previous year were reused. Later, vegetable crops were supported by trellis made with bamboo and plastic rope arrangements. Trellises were made in the middle of the plot to minimize the shading effect on rice 
crop. Intercultural operations were done and plant protection measures were taken as per requirement of the rice-cum-vegetable cultivation. Five rice hills were selected randomly from each plot and uprooted before harvesting for recording data other than yields. After sampling the whole plot was harvested at maturity on 19 May 2005. The harvested plants of each plot were separately bundled, properly tagged and then threshed and the fresh weights of grain and straw were recorded plot wise. The grain weight was assessed at a 14\% moisture level. Finally, grain and straw yields were recorded and converted to $\mathrm{t} \mathrm{ha}^{-1}$. Here, vegetable yield assessment was made not on the basis of area on which vegetables were grown but on the basis of whole plot. Rice equivalent yield, gross return, net return and benefit-cost ratio were also calculated. Data were analyzed and the mean differences were adjudged among the treatments by Duncan's Multiple New Range Test (Gomez and Gomez, 1984).

\section{Results AND Discussion}

\section{Effect of vegetable crop combination}

It was found from the experiment that crop combination exhibited significant influence on number of effective and total tillers hill ${ }^{-1}$, number of grains panicle ${ }^{-1}$, grain and straw yields together with vegetable and rice equivalent yields while other characters remained unaffected (Table1). The number of effective tillers hill ${ }^{-1}$ was highest $(14.27)$ in rice alone $\left(C_{0}\right)$ and this was significantly similar to that in rice + bitter gourd $\left(\mathrm{C}_{4}\right)$. The lowest number of effective tillers hill $^{-1}$ (13.62) was found in rice + white gourd $\left(C_{2}\right)$ and rice + snake gourd $\left(C_{3}\right)$, respectively. No regular trend in total tiller production was found in this study. The highest tiller production (16.87) was recorded from the control treatment $\left(\mathrm{C}_{0}\right)$, which was similar to that in rice + bitter gourd $\left(\mathrm{C}_{4}\right)$. The lowest tiller production (15.73) was obtained from rice + snake gourd $\left(C_{3}\right)$, which was found similar with that in rice + bottle gourd $\left(C_{1}\right)$ and rice + white gourd $\left(C_{2}\right)$ crop combinations. The control treatment $\left(C_{0}\right)$ produced higher grains panicle ${ }^{-1}(137.8)$, which was similar to that in rice + bitter gourd $\left(\mathrm{C}_{4}\right)$ and rice + bottle gourd $\left(C_{1}\right)$ followed by rice + white gourd $\left(C_{2}\right)$ and the lowest grains panicle ${ }^{-1}(126.2)$ was obtained from rice + snake gourd $\left(\mathrm{C}_{3}\right)$ crop combination. The trellis-grown bitter gourd $\left(\mathrm{C}_{4}\right)$ and bottle gourd $\left(C_{1}\right)$ did not significantly reduce rice yields compared to that obtained from sole rice plot. On the other hand, significant rice yield reductions were achieved with white gourd $\left(\mathrm{C}_{2}\right)$ and snake gourd $\left(\mathrm{C}_{3}\right)$. However, seed yield reductions due to trellis-grown vegetable were just marginal. The lowest grain yield of rice $\left(4.64 \mathrm{t} \mathrm{ha}^{-1}\right)$ was obtained from the crop combination of rice + snake gourd $\left(\mathrm{C}_{3}\right)$ with yield reduction of only $9.0 \%$ as compared with sole rice cropping. Grain yield of rice was slightly affected by hail storm just before the harvest of rice crop. The changes in straw yield due to crop combination were almost similar to grain yield. No significant straw yield reductions occurred with bitter gourd $\left(\mathrm{C}_{4}\right)$ and bottle gourd $\left(\mathrm{C}_{1}\right)$. Marginal reductions happened with white gourd $\left(C_{2}\right)$ and snake gourd $\left(C_{3}\right)$. Regarding vegetable yield, white gourd $\left(C_{2}\right)$ on the ails of Boro rice plots gave the highest yield of $14.52 \mathrm{tha}^{-1}$ followed by $9.73 \mathrm{t} \mathrm{ha}^{-1}$ of bottle gourd $\left(\mathrm{C}_{1}\right)$. The production of snake gourd $\left(C_{3}\right)$ was moderate $\left(4.19 \mathrm{t} \mathrm{ha}^{-1}\right)$ and bitter gourd $\left(\mathrm{C}_{4}\right)$ had the lowest vegetable yield $\left(1.06 \mathrm{t} \mathrm{ha}^{-1}\right)$. Moreover, vegetable crops were also partially affected by hail storm during the fruiting stage. It was found that all the vegetable combinations other than bitter gourd $\left(\mathrm{C}_{4}\right)$ had remarkable rice equivalent yields compared to sole rice crop $\left(5.09 \mathrm{t} \mathrm{ha}^{-1}\right)$. The highest value $\left(18.40 \mathrm{t} \mathrm{ha}^{-1}\right)$ was obtained with white gourd $\left(\mathrm{C}_{2}\right)$ followed by $14.10 \mathrm{t} \mathrm{ha}^{-1}$ in bottle gourd $\left(\mathrm{C}_{1}\right)$ and $8.58 \mathrm{t} \mathrm{ha}^{-1}$ in snake gourd $\left(\mathrm{C}_{3}\right)$. More than $200 \%$ to $300 \%$ increases in rice equivalent yields with trellis-grown vegetable of white gourd $\left(C_{2}\right)$ and bottle gourd $\left(C_{1}\right)$. This clearly suggests that rice cum vegetable production with these particular treatments might be considered highly remunerative.

The trellis-grown vegetable crops did not significantly reduce intensity of light in rice crop (Table 1). The lowest intensity of light was obtained from the crop combination of rice + white gourd $\left(C_{2}\right)$ with reduction in interception of solar radiation of only $11.0 \%$ as compared with sole rice cropping. Results also showed that there was no scarcity of light for rice crop. So, both the vegetable and rice crops got enough sunshine. As a result, cultivation of rice did not hampered by vegetable crops. This might be the probable reason of such result. 
Table 1. Yield and yield attributes of Boro rice cv. BRRI dhan29 and vegetable yield as influenced by the crop combination in the rice cum vegetable cultivation system

\begin{tabular}{|c|c|c|c|c|c|c|c|c|c|c|}
\hline $\begin{array}{c}\text { Crop } \\
\text { combination }\end{array}$ & $\begin{array}{l}\text { Plant } \\
\text { height } \\
(\mathrm{cm})\end{array}$ & $\begin{array}{c}\text { No. of } \\
\text { effective } \\
\text { tillers hill }\end{array}$ & $\begin{array}{c}\text { No. of } \\
\text { total } \\
\text { tillers } \\
\text { hill }^{-1}\end{array}$ & $\begin{array}{l}\text { Panicle } \\
\text { length } \\
\text { (cm) }\end{array}$ & $\begin{array}{c}\text { No. of } \\
\text { grains } \\
\text { panicle }^{-1}\end{array}$ & $\begin{array}{c}\text { Grain } \\
\text { yield } \\
\left(\text { tha }^{-1}\right)\end{array}$ & $\begin{array}{l}\text { Straw } \\
\text { yield } \\
\left(\text { tha }^{-1}\right)\end{array}$ & $\begin{array}{c}\text { Vegetable } \\
\text { yield } \\
\left.\text { (tha }^{-1}\right)\end{array}$ & $\begin{array}{c}\text { Rice } \\
\text { equivalent } \\
\text { yield }\left(\text { tha }^{-1} \text { ) }\right.\end{array}$ & $\begin{array}{c}\text { Reduction in } \\
\text { interception of } \\
\text { solar radiation } \\
(\%)\end{array}$ \\
\hline $\begin{array}{l}\mathrm{C}_{0} \text { (Rice } \\
\text { lone) }\end{array}$ & 90.06 & $14.27 a$ & $16.87 a$ & 23.30 & $137.8 \mathrm{a}$ & $5.09 a$ & $5.83 a$ & - & $5.09 \mathrm{e}$ & - \\
\hline $\mathrm{C}_{1}(\mathrm{R}+\mathrm{Bo})$ & 91.07 & $13.83 b c$ & $16.13 b$ & 22.91 & 134.3ab & $4.95 a b$ & $5.70 a$ & $9.73 b$ & $14.10 \mathrm{~b}$ & 10.0 \\
\hline$C_{2}(R+W)$ & 90.64 & $13.62 \mathrm{c}$ & $16.07 \mathrm{~b}$ & 23.54 & $133.3 \mathrm{~b}$ & $4.74 \mathrm{bc}$ & $5.48 b$ & $14.52 \mathrm{a}$ & $18.40 \mathrm{a}$ & 11 \\
\hline $\mathrm{C}_{3}(\mathrm{R}+\mathrm{S})$ & 91.11 & $13.62 \mathrm{c}$ & $15.73 b$ & 23.30 & $126.2 \mathrm{c}$ & $4.64 c$ & $5.39 b$ & $4.19 c$ & $8.58 c$ & 10.0 \\
\hline $\mathrm{C}_{4}(\mathrm{R}+\mathrm{Bi})$ & 91.04 & 14.17ab & $16.80 \mathrm{a}$ & 22.86 & $137.3 a$ & $5.03 a$ & $5.78 a$ & $1.06 \mathrm{~d}$ & $6.94 d$ & 8.0 \\
\hline Level of sig. & NS & 0.01 & 0.01 & NS & 0.01 & 0.01 & 0.01 & 0.01 & 0.01 & 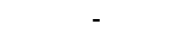 \\
\hline CV (\%) & 3.26 & 3.05 & 3.73 & 3.92 & 3.33 & 5.63 & 4.16 & 8.60 & 6.24 & - \\
\hline
\end{tabular}

In a column, the treatment means having similar letter(s) do not differ significantly

'NS' means not significant

$\mathrm{C}_{0}$ : Rice alone (Control), $\mathrm{C}_{1}:$ Rice + Bottle gourd (Bo), $\mathrm{C}_{2}:$ Rice + White gourd (W),

$\mathrm{C}_{3}:$ Rice + Snake gourd (S), $\mathrm{C}_{4}:$ Rice + Bitter gourd $(\mathrm{Bi})$

\section{Effect of nature of trellis}

Nature of trellis significantly influenced the number of effective and total tillers hill $^{-1}$, number of grains panicle ${ }^{-1}$, grain and straw yields along with vegetable and rice equivalent yields (Table 2). Significant difference in terms of number of effective tillers hill ${ }^{-1}$ was observed for different nature of trellises. The highest number of effective tillers hill ${ }^{-1}$ (14.28) was produced from $T_{2}$ treatment, which was similar to $T_{4}$ treatment and the lowest number (13.18) received from flat trellis $\left(T_{1}\right)$ treatment. Total number of tillers hill ${ }^{-1}$ was significantly affected by the nature of trellis. The highest number of total tillers hill $^{-1}(17.00)$ was recorded from $T_{2}$ treatment, which was identical to $T_{4}$ treatment and followed by $T_{3}$ (16.31) treatment and the lowest number of total tillers hill ${ }^{-1}$ (15.37) was recorded from flat trellis $\left(T_{1}\right)$ treatment. Number of grains panicle ${ }^{-1}$ was statistically different as influenced by nature of trellis. Maximum number of grains panicle ${ }^{-1}$ (139.1) was obtained from $T_{2}$ treatment, which was similar to $T_{4}$ treatment and the minimum value (125.2) received from flat trellis $\left(T_{1}\right)$ treatment. Among nature of trellises, except flat trellis the differences between treatments were not much remarkable. T-trellis with $180 \mathrm{~cm}$ breadth $\left(\mathrm{T}_{2}\right)$ appeared as the best in terms of grain yield of rice. When the breadth of T-trellis was extended $(240 \mathrm{~cm})$, it $\left(T_{3}\right)$ gave the lowest grain yield of rice $\left(4.85 \mathrm{t} \mathrm{ha}^{-1}\right)$. Grain yield reductions due to nature of trellis were significant. Flat trellis $\left(\mathrm{T}_{1}\right)$ showed maximum grain yield reduction (16\%) compared to $\mathrm{T}_{2}(180 \mathrm{~cm}$ breadth $\mathrm{T}$-trellis) treatment. The probable reason might be that flat trellis covered more area over rice plot. As a result, shading effect was more. Similar trend was followed in straw yield as observed in grain yield of rice. Higher straw yield $\left(5.99 \mathrm{t} \mathrm{ha}^{-1}\right)$ was produced from $\mathrm{T}_{2}(180 \mathrm{~cm}$ breadth) treatment, which was identical to $\mathrm{T}_{4}$ treatment and lower straw yield $\left(5.13 \mathrm{t} \mathrm{ha}^{-1}\right)$ was obtained from flat trellis $\left(\mathrm{T}_{1}\right)$ treatment. Higher straw yield was attributed due to higher number of total tillers hill ${ }^{-1}$.

Table 2. Yield and yield attributes of Boro rice cv. BRRI dhan29 and vegetable yield as influenced by the nature of trellis in the rice cum vegetable cultivation system

\begin{tabular}{|c|c|c|c|c|c|c|c|c|c|}
\hline $\begin{array}{c}\text { Nature of } \\
\text { trellis }\end{array}$ & $\begin{array}{c}\text { Plant } \\
\text { height } \\
(\mathrm{cm})\end{array}$ & $\begin{array}{c}\text { No. of } \\
\text { effective } \\
\text { tillers hill }^{-1}\end{array}$ & $\begin{array}{c}\text { No. of } \\
\text { total tillers } \\
\text { hill }^{-1}\end{array}$ & $\begin{array}{l}\text { Panicle } \\
\text { length } \\
\text { (cm) }\end{array}$ & $\begin{array}{c}\text { No. of } \\
\text { grains } \\
\text { panicle }^{-1}\end{array}$ & $\begin{array}{c}\text { Grain } \\
\text { yield } \\
\left(\text { tha }^{-1}\right)\end{array}$ & $\begin{array}{l}\text { Straw } \\
\text { yield } \\
\left(\text { tha }^{-1}\right)\end{array}$ & $\begin{array}{l}\text { Vegetable } \\
\text { yield } \\
\left(\text { tha }^{-1}\right)\end{array}$ & $\begin{array}{c}\text { Rice } \\
\text { equivalent } \\
\text { yield }\left(\text { tha }^{-1} \text { ) }\right.\end{array}$ \\
\hline$T_{1}$ & 90.55 & $13.18 \mathrm{c}$ & $15.37 \mathrm{c}$ & 23.18 & $125.2 \mathrm{c}$ & $4.38 \mathrm{c}$ & $5.13 c$ & $6.85 a$ & $11.08 \mathrm{~b}$ \\
\hline $\mathrm{T}_{2}$ & 90.98 & $14.28 \mathrm{a}$ & $17.00 \mathrm{a}$ & 23.41 & 139.1a & $5.24 a$ & $5.99 a$ & $6.91 \mathrm{a}$ & $11.87 \mathrm{a}$ \\
\hline $\mathrm{T}_{3}$ & 90.31 & $13.88 \mathrm{~b}$ & $16.31 \mathrm{~b}$ & 23.05 & $132.7 b$ & $4.85 b$ & $5.59 \mathrm{~b}$ & $4.93 b$ & $9.59 c$ \\
\hline $\mathrm{T}_{4}$ & 91.30 & $14.27 \mathrm{a}$ & 16.60ab & 23.11 & $137.9 a$ & $5.09 a$ & $5.84 a$ & $4.91 b$ & $9.95 c$ \\
\hline Level of sig. & NS & 0.01 & 0.01 & NS & 0.01 & 0.01 & 0.01 & 0.01 & 0.01 \\
\hline CV (\%) & 3.26 & 3.05 & 3.73 & 3.92 & 3.33 & 5.63 & 4.16 & 8.60 & 6.24 \\
\hline
\end{tabular}

In a column, the treatment means having similar letter(s) do not differ significantly

'NS' means not significant

Note: $\mathrm{T}_{1}$ : Flat trellis, $\mathrm{T}_{2}:$ T-trellis (180 $\mathrm{cm}$ breadth), $\mathrm{T}_{3}$ : T-trellis (240 cm breadth), $\mathrm{T}_{4}: \mathrm{X}$-trellis (Cross trellis) 
Results also showed that nature of trellis exerted significant effect on vegetable yield. T-trellis (180 cm breadth) $\left(T_{2}\right)$ and flat trellis $\left(T_{1}\right)$ produced the highest vegetable yield $\left(6.91\right.$ and $6.85 \mathrm{t} \mathrm{ha}^{-1}$, respectively) followed by T-trellis $\left(240 \mathrm{~cm}\right.$ breadth) $\left(T_{3}\right)$ and the lowest yield $\left(4.91 \mathrm{t} \mathrm{ha}^{-1}\right)$ received from cross trellis $\left(T_{4}\right)$. Rice equivalent yield differed significantly due to nature of trellis. It was observed that T-trellis (180 cm breadth) $\left(T_{2}\right)$ and flat trellis $\left(T_{1}\right)$ were found equally good in terms of producing higher rice equivalent yields (11.87 and $11.08 \mathrm{t} \mathrm{ha}^{-1}$, respectively). X-trellis (cross trellis) and T-trellis (240 cm breadth) were found inferior in terms of producing rice equivalent yields.

\section{Interaction effect of crop combination and nature of trellis}

Number of effective and total tillers hill $^{-1}$, number of grains panicle ${ }^{-1}$, grain, straw, vegetable and rice equivalent yields were influenced significantly by the interaction effect of crop combination and nature of trellis while other characters remained unaffected (Table 3).

Table 3. Yield and yield attributes of Boro rice cv. BRRI dhan29 and vegetable yield as influenced by the interaction effect of crop combination and nature of trellis in the rice cum vegetable cultivation system

\begin{tabular}{|c|c|c|c|c|c|c|c|c|c|c|}
\hline $\begin{array}{l}\text { Crop combination } \\
X \text { Nature of trellis }\end{array}$ & $\begin{array}{l}\text { Plant } \\
\text { height } \\
(\mathrm{cm})\end{array}$ & $\begin{array}{c}\text { No. of } \\
\text { effective } \\
\text { tillers hill }^{-1}\end{array}$ & $\begin{array}{c}\text { No. of } \\
\text { total } \\
\text { tillers hill }\end{array}$ & $\begin{array}{c}\text { Panicle } \\
\text { length } \\
\text { (cm) }\end{array}$ & $\begin{array}{c}\text { No. of } \\
\text { grains } \\
\text { panicle }^{-1}\end{array}$ & $\begin{array}{l}\text { Grain } \\
\text { yield } \\
\left(\text { tha }^{-1}\right)\end{array}$ & $\begin{array}{l}\text { Straw } \\
\text { yield } \\
\left(\text { tha }^{-1}\right)\end{array}$ & $\begin{array}{c}\text { Vegetable } \\
\text { yield } \\
\left(\text { tha }^{-1}\right)\end{array}$ & $\begin{array}{c}\text { Rice } \\
\text { equivalent } \\
\text { yield }\left(\text { tha }^{-1}\right)\end{array}$ & $\begin{array}{l}\text { Reduction in } \\
\text { interception } \\
\text { of solar } \\
\text { radiation (\%) }\end{array}$ \\
\hline one) $\mathrm{XT}_{1}$ & 1.85 & 20.000 y & $16.13 \mathrm{c} \sim \mathrm{g}$ & 22.80 & $5 f g$ & 4.69def & & 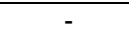 & $4.69 j$ & 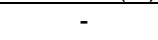 \\
\hline $\mathrm{T}_{2}$ & 88.21 & $14.47 \mathrm{a} \sim \mathrm{d}$ & $18.40 \mathrm{a}$ & 23.50 & 141.0abc & $5.26 a b c$ & $6.01 \mathrm{abc}$ & 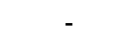 & $5.26 \mathrm{ij}$ & 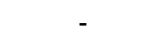 \\
\hline $\mathrm{T}_{3}$ & 88.52 & $14.27 \mathrm{a} \sim \mathrm{e}$ & $16.13 \mathrm{c} \sim \mathrm{g}$ & 23.77 & $134.8 c \sim f$ & $5.19 a \sim d$ & $5.93 a \sim d$ & - & 5.19ij & - \\
\hline $\mathrm{T}_{4}$ & 91.57 & $14.53 a b c$ & $16.80 b \sim f$ & 23.15 & $147.7 \mathrm{a}$ & $5.21 \mathrm{a} \sim \mathrm{d}$ & $5.94 a \sim d$ & - & $5.21 \mathrm{ij}$ & - \\
\hline $\mathrm{C}_{1}(\mathrm{R}+\mathrm{Bo}) \times \mathrm{T}_{1}$ & 90.47 & $13.20 \mathrm{~g}$ & $14.60 \mathrm{~h}$ & 23.43 & $125.9 \mathrm{~g}$ & 4.34fgh & 5.09hij & $11.20 \mathrm{~cd}$ & $14.88 b$ & 14.0 \\
\hline $\mathrm{T}_{2}$ & 92.16 & $14.27 \mathrm{a} \sim \mathrm{e}$ & $16.27 \mathrm{c} \sim \mathrm{g}$ & 23.33 & $141.2 \mathrm{abc}$ & $5.36 a b$ & $6.11 \mathrm{ab}$ & $10.62 d$ & $15.36 b$ & 10.0 \\
\hline $\mathrm{T}_{3}$ & 89.45 & $14.27 \mathrm{a} \sim \mathrm{e}$ & $16.00 \mathrm{~d} \sim \mathrm{g}$ & 22.02 & $137.9 \mathrm{~b} \sim \mathrm{e}$ & 4.53efg & $5.28 f \sim i$ & $9.12 \mathrm{e}$ & $13.11 \mathrm{c}$ & 10.0 \\
\hline $\mathrm{T}_{4}$ & 92.20 & $13.60 \mathrm{efg}$ & $17.67 \mathrm{ab}$ & 22.87 & $132.0 \mathrm{~d} \sim \mathrm{g}$ & $5.56 a$ & $6.31 \mathrm{a}$ & $7.97 f$ & $13.06 \mathrm{c}$ & 7.0 \\
\hline $\mathrm{C}_{2}($ & 89.93 & $13.20 \mathrm{~g}$ & $14.27 \mathrm{~h}$ & 23.52 & $129.3 f g$ & 4.11gh & $4.86 \mathrm{ij}$ & $18.46 a$ & $21.49 a$ & 14.0 \\
\hline $\mathrm{T}_{2}$ & 92.34 & $14.07 b \sim f$ & $17.20 \mathrm{bc}$ & 23.54 & $140.2 a \sim d$ & $5.17 \mathrm{a} \sim \mathrm{d}$ & $5.92 \mathrm{a} \sim \mathrm{d}$ & $17.38 \mathrm{~b}$ & $21.53 a$ & 17.0 \\
\hline $\mathrm{T}_{3}$ & 88.82 & $13.27 \mathrm{fg}$ & $17.07 \mathrm{bcd}$ & 23.52 & $130.9 \mathrm{efg}$ & 4.72def & $5.45^{\mathrm{e}} \sim \mathrm{h}$ & $11.71 \mathrm{c}$ & $15.74 b$ & 13.0 \\
\hline $\mathrm{T}_{4}$ & 91.47 & $13.93 \mathrm{c} \sim \mathrm{g}$ & $15.73 \mathrm{efg}$ & 23.57 & $132.5 d \sim g$ & $4.95 b \sim e$ & $5.70 b \sim f$ & $10.53 d$ & $14.86 \mathrm{~b}$ & 1.0 \\
\hline $\mathrm{C}_{3}$ & 89.58 & $12.33 \mathrm{~h}$ & $15.20 \mathrm{gh}$ & 23.73 & $117.9 \mathrm{~h}$ & $3.97 \mathrm{~h}$ & $4.72 \mathrm{j}$ & 3.69hi & 7.45efg & 10.0 \\
\hline $\mathrm{T}_{2}$ & 92.63 & $13.67 d \sim g$ & $16.27 \mathrm{c} \sim \mathrm{g}$ & 23.17 & $127.1 \mathrm{fg}$ & $5.27 a b c$ & $6.02 \mathrm{abc}$ & $5.61 \mathrm{~g}$ & $10.55 d$ & 12.0 \\
\hline $\mathrm{T}_{3}$ & 91.42 & $13.67 d \sim g$ & $15.67 \mathrm{fg}$ & 23.18 & $126.3 \mathrm{fg}$ & $4.85 b \sim f$ & $5.60 \mathrm{c} \sim \mathrm{g}$ & $3.10 i$ & 7.77efg & 12.0 \\
\hline $\mathrm{T}_{4}$ & 90.82 & $14.80 a b$ & $15.73 \mathrm{efg}$ & 23.13 & $133.5 c \sim g$ & $4.46^{e} \sim h$ & 5.21ghi & $4.34 \mathrm{~h}$ & $8.55 \mathrm{e}$ & 6.0 \\
\hline $\mathrm{C}_{4}$ & 90.90 & $13.33 \mathrm{fg}$ & $16.60 b \sim f$ & 22.40 & $125.6 \mathrm{~g}$ & $4.79 c \sim f$ & $5.54 d \sim g$ & $0.88 \mathrm{jk}$ & 6.91fgh & 5.0 \\
\hline $\mathrm{T}_{2}$ & 89.47 & $14.93 a$ & $16.86 \mathrm{~b} \sim \mathrm{e}$ & 23.48 & 145.9ab & $5.12 \mathrm{a} \sim \mathrm{d}$ & $5.87 \mathrm{a} \sim \mathrm{e}$ & $0.94 \mathrm{jk}$ & $6.67 \mathrm{gh}$ & 13.0 \\
\hline $\mathrm{T}_{3}$ & 93.33 & $13.93 \mathrm{c} \sim \mathrm{g}$ & $16.66 b \sim f$ & 22.76 & $133.6 \mathrm{c} \sim \mathrm{g}$ & $4.94 \mathrm{~b} \sim \mathrm{e}$ & $5.69 b \sim f$ & $0.71 \mathrm{k}$ & $6.11 \mathrm{hi}$ & 9.0 \\
\hline $\mathrm{T}_{4}$ & 90.47 & $14.47 a \sim d$ & $17.07 \mathrm{bcd}$ & 22.82 & 143.9ab & $5.27 a b c$ & $6.02 \mathrm{abc}$ & $1.70 \mathrm{j}$ & 8.07ef & 5.0 \\
\hline Leve & NS & 0.05 & 0.01 & NS & 0.05 & 0.05 & 0.01 & 0.01 & 0.01 & - \\
\hline CV (\%) & 3.26 & 3.05 & 3.73 & 3.92 & 3.33 & 5.63 & 4.16 & 8.60 & 6.24 & - \\
\hline
\end{tabular}

In a column, the treatment means having similar letter(s) do not differ significantly; 'NS' means not significant $\mathrm{C}_{0}$ : Rice (Sole), $\mathrm{C}_{1}$ : Rice + Bottle gourd (Bo), $\mathrm{C}_{2}$ : Rice + White gourd (W), $\mathrm{C}_{3}$ : Rice + Snake gourd (S), $\mathrm{C}_{4}$ : Rice + Bitter gourd $(\mathrm{Bi})$

Note: $\mathrm{T}_{1}$ : Flat trellis, $\mathrm{T}_{2}$ : T-trellis (180 cm breadth), $\mathrm{T}_{3}$ : T-trellis (240 $\mathrm{cm}$ breadth), $\mathrm{T}_{4}: \mathrm{X}$-trellis (Cross trellis)

Number of effective tillers hill ${ }^{-1}$ differed significantly due to interaction effect. The highest number of effective tillers hill ${ }^{-1}(18.40)$ was produced from control treatment and the lowest (12.33) produced from $\mathrm{C}_{3} \mathrm{~T}_{1}$ treatment combination. Effect of interaction for total tillers hill ${ }^{-1}$ was significant. Higher number of total tillers hill $^{-1}$ (18.40) was found in sole rice i.e. control treatment and lower number (14.60) was found in $C_{1} T_{1}$ treatment combination. The variation in number of grains panicle ${ }^{-1}$ differed significantly due to interaction effect. It was found that the maximum number of grains panicle $^{-1}$ (147.7) was produced by the control treatment and the minimum (117.9) was obtained from the $\mathrm{C}_{3} \mathrm{~T}_{1}$ treatment combination. There was significant interaction between crop combination and nature of trellis on grain yield of rice. The highest grain yield $\left(5.56 \mathrm{t} \mathrm{ha}^{-1}\right)$ was found in $\mathrm{X}$-trellis (cross trellis) with bottle gourd $\left(C_{1} T_{4}\right)$ treatment combination and the lowest $\left(3.97 \mathrm{t} \mathrm{ha}^{-1}\right)$ was found in flat trellis with snake gourd $\left(\mathrm{C}_{3} \mathrm{~T}_{1}\right)$ treatment combination. The interaction effect of crop 
combination and nature of trellis was significant in respect of straw yield of BRRI dhan29. Higher straw yield $\left(6.31 \mathrm{t} \mathrm{ha}^{-1}\right)$ was recorded from $\mathrm{C}_{1} \mathrm{~T}_{4}$ treatment combination and lower straw yield $(4.72 \mathrm{t}$ $\mathrm{ha}^{-1}$ ) was obtained from $\mathrm{C}_{3} \mathrm{~T}_{1}$ treatment combination.

The interaction effect of crop combination and nature of trellis was significant in terms of vegetable yield. In vegetable production, the $\mathrm{C}_{2} \mathrm{~T}_{1}$ (white gourd with flat trellis) treatment combination produced the highest yield of $18.46 \mathrm{tha}^{-1}$ followed by $17.38 \mathrm{tha}^{-1}$ of $\mathrm{C}_{2} \mathrm{~T}_{2}$ (white gourd with $180 \mathrm{~cm}$ T-trellis) treatment combination and the lowest vegetable yield $\left(0.71 \mathrm{t} \mathrm{ha}^{-1}\right)$ was recorded from the $\mathrm{C}_{4} \mathrm{~T}_{3}$ (bitter gourd with $240 \mathrm{~cm}$ breadth $\mathrm{T}$-trellis) treatment combination. The effect of interaction on rice equivalent yield was significant. In respect of rice equivalent yield, white gourd $\left(\mathrm{C}_{2}\right)$ with T-trellis (180 cm breadth) and flat trellis $\left(\mathrm{T}_{1}\right)$ produced their superiority with the highest rice equivalent yields (21.53 and $21.49 \mathrm{t} \mathrm{ha}^{-1}$, respectively) compared to $4.69 \mathrm{t} \mathrm{ha}^{-1}$ of rice from sole crop. There was significant difference in terms of light interception of rice due to different interaction effects (Table 3). Results presented in the Table 3 show that different treatment combinations only intercepted the incoming solar radiation ranging from $1.0 \%$ to $17.0 \%$. The results indicated that the shading effect of trellis systems did not influence the growth of Boro rice. So, the possible cause might be that the canopy of vegetable crops did not hamper the light interception of rice plants. The results are in agreement with the results of Kundu (2002).

In vegetable cultivation with Boro rice crop, the highest values of gross return (Tk. 188,925 ha' ${ }^{1}$ ), net return (Tk. 125,259 ha ${ }^{-1}$ ) and benefit-cost ratio (2.97) were obtained from $\mathrm{C}_{2} \mathrm{~T}_{2}$ (rice + white gourd and $180 \mathrm{~cm}$ breadth T-trellis) treatment (Table 4). The lowest values of gross return (Tk. $57,625 \mathrm{ha}^{-1}$ ) and benefit-cost ratio (0.94) were recorded from $\mathrm{C}_{4} \mathrm{~T}_{3}$ (rice + bitter gourd and $240 \mathrm{~cm}$ breadth T-trellis) treatment combination.

Table 4. Cost and return of vegetable cultivation in the ails of Boro rice crop

\begin{tabular}{|c|c|c|c|c|c|c|}
\hline \multirow{2}{*}{$\begin{array}{l}\text { Treatment } \\
\text { combination }\end{array}$} & \multirow{2}{*}{$\begin{array}{l}\text { Total cost of } \\
\text { production } \\
\left(\text { Tk. ha }^{-1}\right)\end{array}$} & \multicolumn{2}{|c|}{ Return (Tk. ha ${ }^{-1}$ ) } & \multirow{2}{*}{$\begin{array}{c}\text { Gross return } \\
\left(\mathrm{Tk} . \mathrm{ha}^{-1}\right) \\
(\mathrm{a}+\mathrm{b})\end{array}$} & \multirow{2}{*}{$\begin{array}{l}\text { Net return } \\
\left(\text { Tk. ha }{ }^{-1}\right)\end{array}$} & \multirow{2}{*}{$\begin{array}{l}\text { Benefit- } \\
\text { cost ratio }\end{array}$} \\
\hline & & $\begin{array}{l}\text { From main } \\
\text { product (a) }\end{array}$ & $\begin{array}{l}\text { From by- } \\
\text { product (b) }\end{array}$ & & & \\
\hline $\mathrm{C}_{0}$ (Rice alone) $\mathrm{XT}_{1}$ & 33,519 & 39,865 & 5,440 & 45,305 & 11,786 & 1.35 \\
\hline $\mathrm{T}_{2}$ & 33,519 & 44,710 & 6,010 & 50,720 & 17,201 & 1.51 \\
\hline $\mathrm{T}_{3}$ & 33,519 & 44,115 & 5,930 & 50,045 & 16,526 & 1.49 \\
\hline $\mathrm{T}_{4}$ & 33,519 & 44,285 & 5,940 & 50,225 & 16,706 & 1.50 \\
\hline $\mathrm{C}_{1}(\mathrm{R}+\mathrm{Bo}) \mathrm{XT}_{1}$ & 65,114 & 126,480 & 5,090 & 131,570 & 66,456 & 2.02 \\
\hline $\mathrm{T}_{2}$ & 65,114 & 130,560 & 6,110 & 136,670 & 71,556 & 2.10 \\
\hline $\mathrm{T}_{3}$ & 65,114 & 111,435 & 5,280 & 116,715 & 51,601 & 1.79 \\
\hline $\mathrm{T}_{4}$ & 65,114 & 111,010 & 6,310 & 117,320 & 52,206 & 1.80 \\
\hline $\mathrm{C}_{2}(\mathrm{R}+\mathrm{W}) \times \mathrm{T}_{1}$ & 63,666 & 182,665 & 4,860 & 187,525 & 123,859 & 2.95 \\
\hline $\mathrm{T}_{2}$ & 63,666 & 183,005 & 5,920 & 188,925 & 125,259 & 2.97 \\
\hline $\mathrm{T}_{3}$ & 63,666 & 133,790 & 5,450 & 139,240 & 75,574 & 2.19 \\
\hline $\mathrm{T}_{4}$ & 63,666 & 126,310 & 5,700 & 132,010 & 68,344 & 2.07 \\
\hline $\mathrm{C}_{3}(\mathrm{R}+\mathrm{S}) \times \mathrm{T}_{1}$ & 61,144 & 63,325 & 4,720 & 68,045 & 6,901 & 1.11 \\
\hline $\mathrm{T}_{2}$ & 61,144 & 89,675 & 6,020 & 95,695 & 34,551 & 1.57 \\
\hline$T_{3}$ & 61,144 & 66,045 & 5,600 & 71,645 & 10,501 & 1.17 \\
\hline $\mathrm{T}_{4}$ & 61,144 & 72,675 & 5,210 & 77,885 & 16,741 & 1.27 \\
\hline $\mathrm{C}_{4}(\mathrm{R}+\mathrm{Bi}) \mathrm{XT}_{1}$ & 61,585 & 58,735 & 5,540 & 64,275 & 2,690 & 1.04 \\
\hline $\mathrm{T}_{2}$ & 61,585 & 56,695 & 5,870 & 62,565 & 980 & 1.02 \\
\hline $\mathrm{T}_{3}$ & 61,585 & 51,935 & 5,690 & 57,625 & $-3,960$ & 0.94 \\
\hline $\mathrm{T}_{4}$ & 61,585 & 68,595 & 6,020 & 74,615 & 13,030 & 1.21 \\
\hline
\end{tabular}

Note: $\mathrm{T}_{1}$ : Flat trellis

$\mathrm{T}_{2}$ : T-trellis (180 cm breadth)

$\mathrm{T}_{3}$ : T-trellis (240 cm breadth)

$\mathrm{T}_{4}$ : X-trellis (Cross trellis)

Rice grain @ Tk. 8.50kg-1 Rice straw @ Tk. $1.00 \mathrm{~kg}^{-1}$
$\mathrm{C}_{0}$ : Rice (Sole)

$\mathrm{C}_{1}$ : Rice + Bottle gourd (Bo)

$\mathrm{C}_{2}$ : Rice + White gourd (W)

$\mathrm{C}_{3}$ : Rice + Snake gourd (S)

$\mathrm{C}_{4}$ : Rice + Bitter gourd $(\mathrm{Bi})$

Bottle gourd@ @ Tk. 8.00 kg $^{-1}$ Snake gourd@Tk. 8.00 kg $^{-1}$
White gourd @ Tk. 8.00 kg $^{-1}$

Bitter gourd@Tk.14.00 kg-1 


\section{CONCLUSION}

From the above study it could be highlighted that vegetable cultivation along with Boro rice crop is remunerative in terms of both yield and economics. Therefore, both flat trellis $\left(T_{1}\right)$ and $T$-trellis with $180 \mathrm{~cm}$ breadth $\left(T_{2}\right)$ were found to be the most suitable trellises for Boro rice cum vegetable cultivation on the ails of growing rice crop.

\section{Literature Cited}

Alam, M. Z. 2000. Dike cropping manual. Interfish- 2 Project. CARE (Co-operative for American Relief Everywhere), Bangladesh.pp. 28-49.

Anonymous. 2006. In "The Daily Ittefaq (In Bangla)". Ram Krishna Mission Road, Dhaka, Bangladesh. p. 2.

BBS (Bangladesh Bureau of Statistics). 2004. Monthly Statistical Bulletin Bangladesh. Bangladesh Bur. Stat., Stat. Div., Min. Planning, Govt. People's Repub. Bangladesh. p. 53 \& 57.

BRRI (Bangladesh Rice Research Institute). 2004. "Adhunik Dhaner Chash (In Bengali)". $10^{\text {th }}$ Ed. Booklet No. 5. Bangladesh Rice Res. Inst., Joydebpur, Gazipur, Bangladesh. pp. 25-28.

Gomes, K. A. and Gomes, A. A. 1984. Statistical Procedure for Agricultural Research. $2^{\text {nd }}$ Ed. John Willey and Sons. New York. pp. 97-111.

Harwood, R. R. 1973. The concept of multiple cropping. An introduction to the principles of cropping system design. Multiple training lecture, (Personal contact).

Kundu, S. K. 2002. Vegatable production in Boro rice crop. M.S. Thesis, Dept. Agron., Bangladesh Agril. Univ., Mymensingh. p. 64.

Siddique, M. A. and Aditya, D. K. 1992. Vegetable consumption and nutrition status in Bangladesh. In "Vegetable production and Marketing". Proc. National Review and Planning Workshop, AVRDC, Shauhua, Taiwan, Taiwan, Pub. No. 92-379. pp. 204-209. 